\title{
Hadis-Hadis tentang Peserta Didik
}

\author{
Amiruddin Siahaan dan Nur Hidayah \\ IAIN Sumatera Utara \\ Email: amiruddin.siahaan@gmail.com
}

\begin{abstract}
This article explains that learners should earnestly seek knowledge or perseverance in either theology or science. In addition, if the students have gained knowledge, then that knowledge should be employed well and teaches it to others. Meanwhile, science is only acquired by learning. Learner is one component input in the education system, which is further processed in the educational process, so that it becomes a qualified human in accordance with the national education goals. A student has a very important role in education. It was described in many traditions (hadis) associated with virtue, character, and requirements of the learners. These hadis will be explained later in this article and will be takhrij to determine the position of these traditions.
\end{abstract}

Keywords: hadis, learner

\begin{abstract}
Abstrak
Artikel ini menjelaskan bahwa peserta didik hendaknya bersungguh-sungguh atau tekun dalam mencari ilmu baik ilmu agama maupun ilmu pengetahuan. Selain itu peserta didik apabila telah mendapatkan ilmu, maka hendaknya ilmu tersebut dipergunakannya dengan baik dan diajarkannya kepada orang lain. Ilmu hanya diperoleh dengan belajar. Peserta didik adalah salah satu komponen masukan dalam sistem pendidikan, yang selanjutnya diproses dalam proses pendidikan, sehingga menjadi manusia yang berkualitas sesuai dengan tujuan pendidikan nasional. Seorang pelajar memiliki peran yang sangat penting dalam pendidikan. Hal itu dijelaskan dalam banyak hadis yang berkaitan dengan kebajikan, karakter, dan persyaratan peserta didik. Hadis-hadis ini akan dijelaskan nanti dalam artikel ini dan akan ditakhrijj untuk mengetahui posisi hadis-hadis tersebut.
\end{abstract}

Kata kunci: hadis, peserta didik 


\section{A. Pendahuluan}

Peserta didik merupakan raw material atau bahan mentah dalam proses transformasi pendidikan. Dalam Undang-undang No. 20 Tahun 2003, dijelaskan bahwa peserta didik adalah anggota masyarakat yang berusaha mengembangkan potensi diri melalui proses pembelajaran yang tersedia pada jalur, jenjang dan jenis pendidikan tertentu.

Dalam membicarakan peserta didik, ada tiga hal penting yang harus diperhatikan oleh pendidik yaitu: (1) potensi peserta didik, (2) kebutuhan peserta didik, dan (3) sifat-sifat peserta didik. Peserta didik dalam arti luas adalah setiap orang yang berkaitan dengan proses pendidikan sepanjang hayat, sedangkan dalam arti sempit adalah setiap siswa yang belajar di sekolah. Kementerian Pendidikan dan Kebudayaan menegaskan bahwa peserta didik adalah anggota masyarakat yang berusaha mengembangkan dirinya melalui jalur, jenjang, dan jenis pendidikan. Peserta didik Usia SD/MI adalah semua anak yang berada pada rentang usia 6 sampai 12 atau 13 tahun.

Peserta didik adalah komponen masukan dalam sistem pendidikan, yang selanjutnya diproses dalam proses pendidikan, sehingga menjadi manusia yang berkualitas sesuai dengan tujuan pendidikan nasional. Sebagai suatu komponen pendidikan, peserta didik dapat ditinjau dari berbagai pendekatan, antara lain:

1. Pendekatan sosial. Peserta didik adalah anggota masyarakat yang sedang disiapkan untuk menjadi anggota masyarakat yang lebih baik. Sebagai anggota masyarakat, dia berada dalam lingkungan keluarga, masyarakat sekitarnya, dan masyarakat yang lebih luas. Peserta didik perlu disiapkan agar pada waktunya mampu melaksanakan perannya dalam dunia kerja dan dapat menyesuaikan diri di masyarakat. Kehidupan bermasyarakat itu dimulai dari lingkungan keluarga dan dilanjutkan di dalam lingkungan sekolah. Dalam konteks inilah, peserta didik melakukan interaksi dengan rekan sesamanya, guru-guru, dan masyarakat yang berhubungan dengan sekolah. Dalam situasi inilah nilai-nilai sosial yang terbaik dapat ditanamkan secara bertahap melalui proses pembelajaran dan pengalaman langsung.

2. Pendekatan psikologis. Peserta didik adalah suatu organisme yang sedang tumbuh dan berkembang. Peserta didik memiliki berbagai potensi manusiawi, seperti: bakat, minat, kebutuhan, sosial-emosional-personal, dan kemampuan jasmaniah. Potensi 
itu perlu dikembangkan melalui proses pendidikan dan pembelajaran di sekolah, sehingga terjadi perkembangan secara menyeluruh menjadi manusia seutuhnya. Perkembangan menggambarkan perubahan kualitas dan kemampuan dalam diri seseorang, yakni adanya perubahan dalam struktur, kapasitas, fungsi, dan efisiensi. Perkembangan itu bersifat keseluruhan, misalnya perkembangan intelegensi, sosial, emosional, spiritual, yang saling berhubungan satu dengan lainnya.

3. Pendekatan edukatif/pedagogis. Pendekatan pendidikan menempatkan peserta didik sebagai unsur penting, yang memiliki hak dan kewajiban dalam rangka sistem pendidikan menyeluruh dan terpadu.

Dalam bahasa Arab dikenal juga istilah yang sering digunakan untuk menunjukkan pada anak didik. Istilah tersebut adalah murid yang secara harfiah berarti orang yang menginginkan atau membutuhkan sesuatu, tilmiż yang berarti murid, dan tălib al-ilm yang menuntut ilmu, pelajar. Ketiga istilah tersebut seluruhnya mengacu kepada seorang yang tengah menempuh pendidikan. Berdasarkan pengertian di atas, maka dapat disimpulkan bahwa ciri-ciri siswa atau peserta didik adalah sebagai orang yang tengah memerlukan pengetahuan atau ilmu, bimbingan, dan pengarahan.

Untuk mencapai keberhasilan pendidikan diperlukan hubungan kerja sama antara pendidik dan peserta didik, sebaik apapun upaya seorang guru dalam menanamkan pengetahuan, namun jika tidak ada kesanggupan, kesiapan dari peserta didik maka proses pembelajaran sulit untuk mencapai kata berhasil.

Menurut al-Gazā̄i ilmu pendidikan Islam mengungkapkan tugas peserta didik antara lain:

1. Mensucikan diri dari akhlak dan sifat tercela.

2. Keikhlasan menjadi seorang murid untuk belajar kepada seorang guru.

3. Memiliki tanggung jawab untuk berkonsentrasi dan serius dalam belajar.

4. Tidak memiliki sifat sombong kepada guru dan ilmu

5. Tidak mempelajari suatu ilmu secara keseluruhan sekaligus. Mempelajari suatu ilmu dari yang mudah kemudian yang susah.

6. Mempelajari ilmu disesuaikan dengan kebutuhan, tingkat, tahap perkembangan murid. 
7. Mengetahui kedudukan ilmu terhadap tujuan agar tidak mendahulukan ilmu yang tidak penting atas ilmu yang penting. ${ }^{1}$

Demikian pentingnya seorang peserta didik, maka begitu banyak hadis-hadis yang berkenaan dengan keutamaan, karakteristik serta syarat yang dimiliki peserta didik. Hadis-hadis tersebut akan diuraikan dalam artikel ini kemudian di-takhrijj dan akan diketahui kedudukan hadis yang dimaksud.

\section{B. Takhrīj Hadis}

Jika ditelusuri dengan baik, hadis yang berkaitan atau memiliki hubungan dengan peserta didik dari semua aspek yang bersentuhan dengannya sangat banyak dijumpai dalam beberapa kitab hadis yang otoritasnya diakui, seperti halnya kutub al-tis'ah. Penjelasan hadis tersebut memiliki redaksi yang berbeda-beda, sehingga harus ada ketelitian bagi yang menelusurinya. Oleh karena itu, makanya penulis merasa agak kesulitan untuk mendeteksi secara pasti berapa jumlah hadis yang berkaitan dengan peserta didik secara umum, baik dari kecerdasannya maupun karakteristiknya ketika melakukan proses belajar mengajar atau menuntut ilmu pengetahuan.

Peserta didik adalah orang yang berada dalam fase pertumbuhan dan perkembangan, baik secara fisik maupun psikis. Dengan demikian, ia tidak bisa disamakan dengan orang dewasa yang berukuran kecil karena mempunyai spesifikasi tersendiri. Rasulullah saw., sangat memberikan perhatian terhadap pengembangan ilmu pengetahuan. Sehingga ditemukan hadis-hadis yang membicarakan tentang mencari ilmu pengetahuan. Perhatian yang demikian tinggi, karena Rasulullah saw. juga menyatakan dirinya sebagai pendidik. Rasulullah saw. lebih mengutamakan majelis orang yang belajar dari pada majelis ahli ibadah. Di antara hadis yang membicarakan tentang peserta didik adalah sebagai berikut:

Pertama, hadis yang diriwayatkan oleh Bukhāri, bersumber dari Mu'awiyah Khațīban: ${ }^{2}$

${ }^{1} \mathrm{Abu}$ Ḥamīd Al-GāzāTi, Ihyyā 'Ulūm al-Dīn, Jil.1, (Beirut: Dār al-Fikr, 1991), hlm. 22.

${ }^{2}$ Dalam redaksi (matan) hadis yang lain ditemukan: "Menceritakan kepada kami Musaddad, berkata menceritakan kepada kami Basyïr, ia berkata, menceritakan kepada kami Ibn 'Aub, dari Ibn Sirīn, dari Abdurraḥmān ibn Abū Bakrah dari ayahnya. Nabi saw., bersabda "barang siapa dikehendaki baik dari Allah, maka ia dikaruniai kepahaman agama. Sesungguhnya ilmu itu hanya diperoleh dengan belajar (H.R. Bukhārī). 


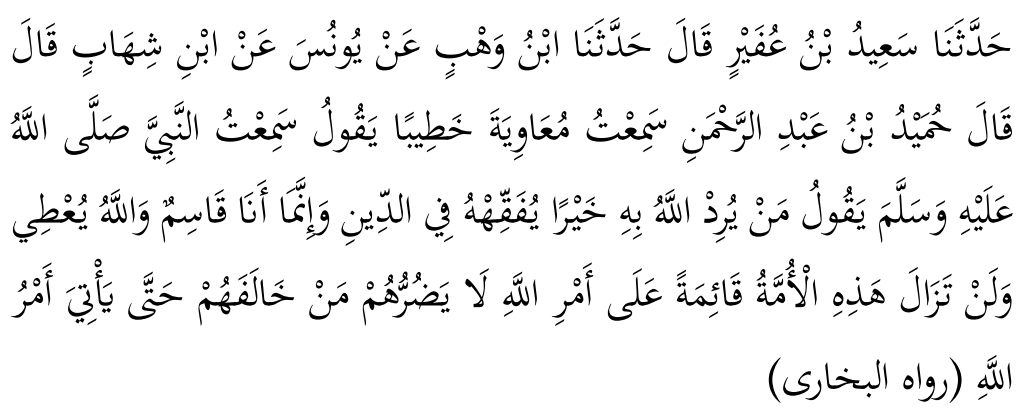

Dari uraian hadis di atas, untuk mewujudkan peserta didik yang berkualitas berdasarkan tinjauan hadis dapat dikemukakan bahwa Rasulullah saw, menjelaskan bahwa ilmu itu hanya diperoleh dengan belajar. Artinya, seseorang tidak bisa hanya bercita-cita, akan tetapi harus di iringi dengan ikhtiar. Orang-orang yang berikhtiar untuk belajar, kelak akan dikaruniai kepahaman agama yang pada akhirnya akan menghantarnya menuju kemuliaan dan kebaikan.

Kedua, hadis yang diriwayatkan oleh Bukhāri, bersumber dari Abdullāh ibn Mas'ūd:

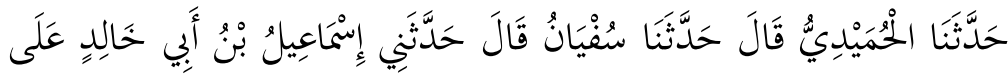

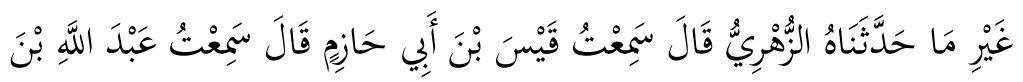

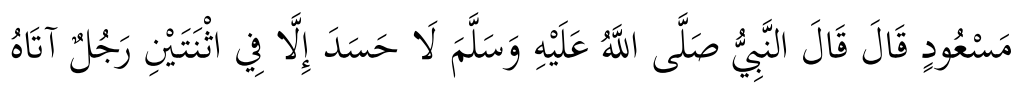

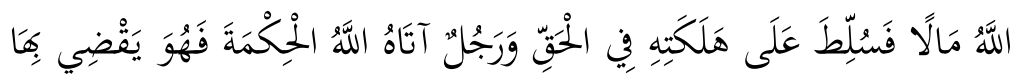

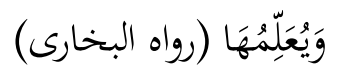

"Menceritakan kepada kami Humaid, ia berkata, menceritakan kepada kami Sufyān, ia berkata, menceritakan kepadaku Ismā'il ibn Abu Khālid atas selain yang kami ceritakan olehnya al-Zuhriy, ia berkata, "aku mendengar Ibn Qais ibn Abu Ḥāzim, ia berkata, aku mendengar 'Abdullāh ibn Mas'ūd berkata, Nabi saw., bersabda, "tidak boleh iri hati kecuali dua hal, yaitu seorang laki-laki yang diberi harta oleh Allah lalu harta itu di kuasakan penggunaannya dalam kebenaran, dan seorang laki-laki di beri hikmah oleh Allah di mana ia memutuskan perkara dan mengajar dengannya" (H.R. Bukhāri).

Hadis di atas memberikan pemahaman bahwa sebagai peserta didik hendaknya bersungguh-sungguh atau tekun dalam mencari ilmu baik ilmu agama maupun ilmu pengetahuan. Peserta didik diserukan agar menjadi ilmuwan atau orang yang pintar sebelum ia 
menikah atau menjadi pemimpin. Peserta didik tidak diperbolehkan iri hati kepada orang lain kecuali dalam dua hal yaitu ilmu dan kebaikan. Peserta didik diserukan untuk berlomba-lomba belajar atau menuntut ilmu dalam suatu kebaikan. Sebagai peserta didik apabila telah mendapatkan ilmu, maka hendaknya ilmu tersebut dipergunakannya dengan baik dan diajarkannya kepada orang lain.

Ketiga, hadis yang diriwayatkan oleh Bukhārī, bersumber dari Abu Hurairah ra:

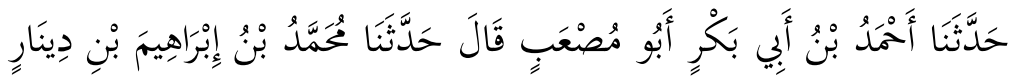

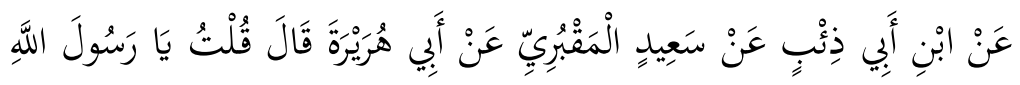

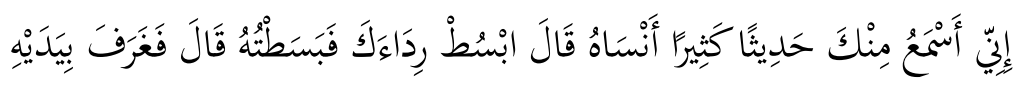

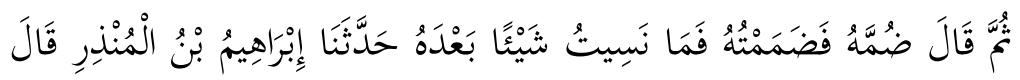

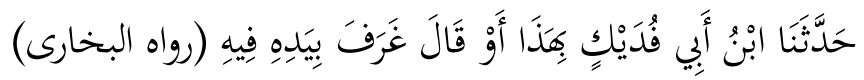

"Menceritakan kepada kami Ahmad ibn Abū Bakar al-Ṣiddiq Abū Mus'ab, ia berkata, menceritakan kepada kami Muḥmmad ibn Ibrāhìm ibn Dīnār, dari Ibn Abi Żi'bu, dari Sa'īd al-Maqburìy, dari Abū Hurairah, ia berkata, aku berkata kepada Rasulullah saw., "wahai Rasulullah, sesungguhnya aku banyak mendengar hadis dari engkau, lalu aku lupa?" Rasulullah saw., bersabda, "hilangkan perkara yang burukmu," lalu aku menghilangkannya... lalu Rasulullah saw., bersabda, "hafalkanlah" lalu aku menhapalkannya," setelah itu aku tidak melupakan suatu hadis pun setelah itu," (HR. Bukhāri).

Hadis di atas memberikan pemahaman bahwa peserta didik hendaknya menuliskan ilmu yang disampaikan oleh pendidik, sehingga terjaga. Sekiranya terlupakan masih bisa dilihat catatannya dan mengulangi kembali pelajaran yang telah diberikan pendidik meskipun dalam jangka waktu yang lama. Peserta didik hendaknya menyadari bahwa dalam menuntut ilmu tersebut, ia berada dalam rida Allah swt., dan mempermudah baginya jalan menuju surga. Peserta didik hendaknya berniat untuk mengajarkan ilmu yang diperolehnya untuk disebarkan dan diajarkan kepada orang lain agar bermanfaat bagi dirinya dan bagi orang lain. Peserta didik tidak boleh malu belajar, karena orang yang malu dan sombong tidak akan dapat mempelajari ilmu agama. Sebaik-baik pelajar adalah yang tidak malu bertanya atas apa yang belum dipahaminya serta tidak melanggar etika peserta didik. 
Keempat, hadis yang diriwayatkan oleh Bukhāri, bersumber dari Abū Hurairah ra:

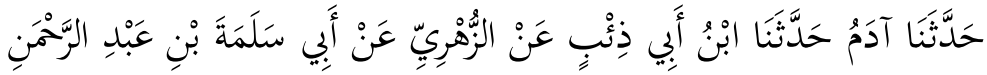

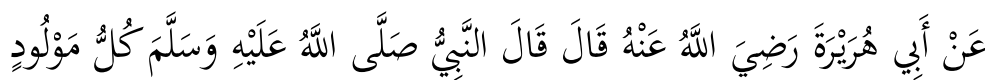

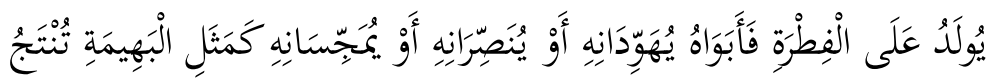

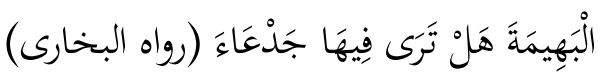

"Menceritakan kepada kami Ādam dari Abì Żi'bin dari alZuhrȳ dari Abī Salmah bin Abd al-Raḥmān dari Abi Hurairah ra., meriwayatkan bahwa Nabi Muhammad saw. bersabda "Setiap anak dilahirkan menurut fitrah (potensi beragama Islam). Selanjutnya, kedua orang tuanyalah yang membelokkannya menjadi Yahudi, Nasrani, atau Majusi bagaikan binatang melahirkan binatang, apakah kamu melihat kekurangan padanya? (HR. Bukhāri).

Dari hadis di atas ada dua hal yang dapat di pahami yaitu, pertama: setiap manusia yang lahir memiliki potensi, baik potensi beragama, potensi menjadi orang baik, potensi menjadi orang jahat dan potensi yang lainya. Kedua: potensi tersebut dapat dipengaruhi oleh lingkungan terutama orang tua karena merekalah yang pertama yang sangat berperan dalam menjadikan anaknya menjadi Yahudi, Nasrani atau Majusi.

Konsep hadis tersebut sesuai dengan teori konvergensi pada perkembangan peserta didik, yang berpendapat bahwa setiap anak yang lahir, dalam perkembangannya di pengaruhi oleh keturunan dan lingkungan. Yaitu setiap anak yang lahir akan di pengaruhi oleh keturunannya, contoh anak yang terlahir dari keluarga yang baikbaik tentunya dia akan menjadi anak yang baik serta dipengaruhi oleh lingkungannya. Hanya saja dalam konsep hadis di atas secara umum manusia lahir memiliki potensi yang sama.

Demikian beberapa hadis yang penulis kutip berdasarkan penelusuran yang telah penulis lakukan. Penelusuran ini tidak menutup kemungkinan bahwa akan ditemukan sekian banyak hadis lagi yang berkaitan dengan peserta didik.

\section{Kritik Sanad}

Urgensi penelusuran terhadap sanad dalam melakukan takhrij hadis merupakan langkah yang tidak bisa dihindarkan dalam 
kaitannya dengan memahami bagaimana eksistensi dan status hadis tersebut dalam perspektif ulama hadis yang menekuni bidangnya. Sehingga, dari proses ini dapat diketahui apakah hadis tersebut memiliki kekuatan untuk diamalkan atau tidak dalam kehidupan sehari-hari, khususnya dalam kaitannya dengan pendidikan yang sedang menjadi topik bahasan dalam makalah ini.

Dari beberapa hadis yang penulis uraikan di atas, akan ditelusuri hadis yang bersumber dari Abū Hurairah ra., yang diriwayatkan oleh Imām Bukhāri, dengan penjelasan sanad berikut ini:

1. Abū Hurairah, nama lengkapnya 'Abd al-Raḥmān bin Sakhr, tingkatan beliau adalah sahabat Nabi saw., panggilan beliau adalah Abū Hurairah, lahir di Madinah dan wafat di Madinah pada tahun 57 Hijriah. Guru beliau ada 14 orang sahabat Nabi saw. di antaranya: Abi bin Ka'ab bin Qais, Bașrah bin Abi Bașrah, Aisyah binti Abu Bakr al-Ṣiddiq, Umar bin al-Khațāa bin Nufail, Usmān bin Affan, Ađì bin Abì Țālib bin 'Abd alMuṭāllib, dan sahabat-sahabat Nabi saw., lain yang pernah menjadi guru Abū Hurairah. Sedangkan murid beliau ada 411 orang, di antaranya: Ibrahīm bin Isma'īil, Isḥāq Maula Zāidah, As'ad bin Sahl bin Hanifif, Anas bin Hakìm, Sa'id bin Abi Sa`ỉd Kaisan, Hafṣah bin Ḥanān, dan murid lainnya. ${ }^{3}$

2. Sa`ỉd al-Maqburȳ, nama lengkapnya Sa`id bin Abi Sa`ỉd Kaisan, tingkatannya tābi'inn, panggilan beliau Abū Sa'id, lahir di Madinah dan wafat pada tahun 123 Hijriah. Beliau menekuni bidang hadis dengan belajar kepada 41 orang guru, di antaranya: Abu Sa’ìd Maula al-Mahrȳ, 'Abd al-Raḥmān bin Sakhr, Anas bin Mālik, Basyīr bin al-Mahrār, Salim bin 'Abd al-Lāh, A' 'isyah binti Abū Bakr as-Ṣiddiq, 'Abd al-Lāh bin Rafi' dan guru beliau lainnya. Sedangkan murid yang pernah berguru kepada Sa'id alMaqburȳ ada 60 orang, di antaranya: Ibrahīm bin al-Faḍl, Usāmah bin Zaid, Ayyūb bin Abi Masākin, Hamīd bin Ziyād, Salmah bin Dīnār, Talhah bin Abi Sa’ìd, Lais bin Sa'ỉd bin 'Abd al-Raḥmān, Muhammad bin 'Abd al-Rạ̣mān bin al-Mugīrah bin al-Harīis bin Abu Żi'bu, Muhammad bin Ajla, al-Wāhid bin al-Karim, dan beberapa murid lain. Rutbah beliau adalah siqah.

\footnotetext{
${ }^{3}$ Ibnu Hajar, Abul Faḍil Ahmad bin 'Ali Al-'Aśqalanī, Al-Hafîdh, tahzỉbut tahzīb, Cet. I, (India: Mathba’ah Majlis Dairah Al-Ma’arif, 1366 H), hlm. 152 .
} 
Ahmad bin Hambal menilai al-Maqbury dengan mengatakan: laisa bihi ba'šnn; al-'Ajalli mengatakan: siqah; al-Madāni mengatakan: siqah ma'mūn; al-Nasa'i mengatakan: siqah; Abū Zarah ar-Razi mengatakan: siqah dan Abu Hatīm al-Rāzi mengatakan: siqah. ${ }^{4}$

3. Ibn Abi Żi'bun, dengan nama lengkap Muhammad bin 'Abd alRaḥmān bin al-Mugirah bin al-Harìs bin Abū Żi'bun, tingakatannya tābi'inn, nama panggilan yang populer adalah Abù al-Harìis, tingkatan beliau adalah tabi'in dilahirkan di Madinah dan wafat di Kufah pada tahun 158 Hijriah. Ibn Abi Żi'bun berguru kepada 48 orang ulama (ahli hadis), di antaranya: alMunżir bin Abì al-Munżir, Ishāa bin Yazid, al-Harìis bin Abd alRaḥmān, Sa’id bin Abi Sa’ìd Kaisan, Syu'bah bin Dīnār, Șālih bin Abi Hasan, 'Abd al-Raḥmān bin Sa'id, dan guru beliau lainnya. Sedangkan murid yang pernah belajar dengan Hammad ada 62 orang, antara lain: Khalf bin al-Walid, Yazid bin Hārūn, Yahya bin Yamān, Umar bin Sa'id bin 'Ābid, Muhammad bin Ibrahīm bin Dīnār, Sulaimān bin Hayyān, dan murid beliau lainnya. Rutbah beliau adalah siqah. Penilaian beberapa ulama hadis tentang Ibn Abi Żi'bun, antara lain: Yahya bin Ma’in mengatakan: siqah, an-Nasa'i mengatakan: siqah; Ahmad bin Hanbal mengatakan: siqah săduq; Ya'kūb bin Syu'bah mengatakan: siquahṣāduq; dan Ibn Hibbān mengatakan: żikruhu fi as-siqah. $^{5}$

4. Muhammad bin Ibrahīm bin Dīnār, nama lengkapnya adalah Muhammad bin Ibrahīm bin Dīnār, tingkatannya tābi'īn, panggilan yang populer yaitu 'Abu Abd al-Lāh, dilahirkan di Madinah dan wafat tahun 182 Hijriah. Guru beliau hanya ada 1 orang, yaitu Muhammad bin 'Abd al-Raḥmān bin al-Mugirah bin al-Harīs bin Abu Żi'bun. Sedangkan murid beliau juga hanya ada 1 orang, yaitu Ahmad bin Abi Bakr al-Qasim bin al-Haris bin Zararah bin Muș'ab bin 'Abd al-Rahmān bin 'Auf. Rutbah beliau adalah siqah. Penilaian para ahli hadis mengenai beliau dalam mengeluarkan hadis, yakni: Bukhāri mengatakan: ma'rūf al-ḥadis (memahami hadis), Abū Ḥatìm al-Razì mengatakan:

${ }^{4}$ Ibnu Hajar, Abul Fađ̣il Ahmad bin 'Ali Al-'Aśqqalanī, Al-Ḥafĩz, Taqribut Tahżíb, Cet. I, (ttp, Darul Fikr, 1415 H/1995 M), hlm. 342.

${ }^{5}$ Ibnu Hajar, Taqrībut Tahżīb, hlm. 243. 
siqah, al-Dāruquṭīi mengatakan: śiqah, dan Ibnu Ḥibbān mengatakan: siqah. ${ }^{6}$

5. Ahmad bin Abi Bakr Abu Muș'ab, nama lengkap beliau Ahmad bin Abi Bakr al-Qāsim bin al-Harīis bin Zararah bin Muș'ab bin 'Abd al-Raḥmān bin 'Auf, tingkatannya, tābi'it- tābi'inn panggilan beliau Abu Muṣ'ab lahir di Madinah dan wafat pada tahun 242 Hijriah. Guru beliau keseluruhannya berjumlah 8 orang, antara lain: 'Abd al-Raḥmān bin Zaid bin Aslam, 'Abd a'Azìz bin Imrān bin 'Abd al-'Aziz, 'Abd al-'Azìiz bin Muḥammad bin Ubaid bin Abì 'Ubaid, Abd al-Muhaimīn bin Abbas bin Sahl bin Sa'īi, Mālik bin Anas bin Mālik bin Abī Amīn, Muḥammad bin Ibrāhīm bin Dīnār, Mahrar bin Ḥanān bin 'Abd al-Lāh, dan al-Mugīah bin 'Abd al-Raḥmān bin al-Ḥaris. Sedangkan murid beliau ada 2 orang yaitu: al-Haris bin Yazid dan Zakaria bin Yahya bin Iyas. Rutbah beliau adalah șăduq, sedangkan penilaian terhadap Aḥmad bin Abū Bakr bin Muṣ'ab antara lain: Abū Zarah al-Rāzi mengatakan șāduq, Abū Ḥatīm al-Rāzì mengatakan șāduq, Ibnu Ḥibbān mengatakan muttaqīn, dan al-Ḥakim mengatakan alim bi-mażhab ahl al-madinah. ${ }^{7}$

Dengan menelusuri sanad yang terdapat dalam hadis Imam Bukhari ini, penulis dapat mengambil kesimpulan bahwa hadis tersebut dapat dikatakan sahih dan bisa dijadikan hujjah dalam kaitannya dengan pendidikan, khususnya mengenai peserta didik.

\section{Pemahaman Hadis lain Berkaitan dengan Peserta Didik}

Peserta didik merupakan salah satu komponen dalam suatu pendidikan secara formal adalah orang yang sedang berada dalam fase pertumbuhan dan perkembangan baik secara fisik, maupun psikis. Menurut pasal 1 ayat 4 UU RI No. 20 tahun 2003 tentang pendidikan Nasional, peserta didik adalah anggota masyarakat yang berusaha mengembangkan dirinya melalui proses pendidikan pada jalur, jenjang dan jenis pendidikan tertentu. Demikian penting seorang peserta didik, maka begitu banyak hadis-hadis yang berkenaan dengan keutamaan, karakteristik serta syarat yang dimiliki peserta didik, di antaranya:

'Ibnu Hajar, Abul Fadhil Ahmad bin 'Ali Al-'Asqalani, Al-Hafidh, Tahzīibut Tahzīib, hlm. 123.

${ }^{7}$ Ibnu Hajar, Tahżibut Tahżīb, hlm. 105. 
1. Terhindar dari kutukan Allah. Dari Abu Hurairah, ia berkata: Saya mendengar Rasulullah saw. bersabda: "Sesungguhnya dunia dan isinya terkutuk, kecuali zikrullah dan hal-hal terkait dengannya, alim (guru), dan peserta didik".Dari hadis di atas jelaslah bahwa salah satu yang tidak terhindar dari kutukan Allah adalah peserta didik, hal ini karena peserta didik merupakan sosok yang sedang mencari kebenaran yaitu dengan menuntut ilmu, sehingga ketika pendidik telah memiliki ilmu derajatnya akan di angkat oleh Allah swt. Sebagai pendidik harus bisa memahami dan menghargai keutamaan pada peserta didik tersebut, agar terjadinya dalam proses pembelajaran rasa saling menghargai, menghormati serta saling menyayangi.

2. Menempati posisi terbaik. Dari Abi Umamah, ia berkata: Rasulullah saw. bersabda: "hendaklah kamu ambil ilmu ini. Orang alim (pendidik) dan muta'allim (peserta didik) berserikat dalam pahala dan tidak ada manusia yang lebih baik daripadanya". Dalam hadis tersebut, dapat dipahami bahwa pendidik dan peserta didik merupakan manusia yang lebih baik. Hal ini perlu diperhatikan oleh pendidik agar tidak terjadinya otoriter dalam mengajar, serta guru merasa lebih sombong di depan peserta didiknya. Terdapat juga dalam hadis lain, yaitu: Usmān ibn Affan berkata, Rasulullah saw. bersabda: "Sesungguhnya orang yang paling utama di antara kamu adalah orang yang mempelajari al-Qur'an dan mengajarkannya". Hadis ini menjelaskan orang yang paling utama adalah yang mempelajari al-Qur'an dan mengajarkannya.

3. Peserta didik harus ikhlas. Ikhlas menurut bahasa adalah jujur dan tulus. Kata ikhlas berasal dari ism mașdar akhlașa, yukhliṣu, ikhlāṣan yang berarti murni dan tanpa campuran. Dari definisi tersebut maka ikhlas dapat di artikan dengan pemurnian niat yang di kotori oleh ambisi pribadi dan sifat ingin dipuji orang lain kepada niat semata-mata untuk mengharap rida Allah swt dalam melakukan perbuatan. Sebaliknya, jika peserta didik tidak memiliki keikhlasan maka ilmu yang akan merasa sulit dipahami bahkan Rasulullah saw. mengatakan tidak akan mencium bau surga, sebagaimana sabda Nabi saw.: Dari Mu'az ibn Jabal, Rasulullah saw. bersabda: "Siapa yang menuntut ilmu karena ingin merasa bangga sebagai ulama, menipu orang bodoh di majelis tidak akan mencium aroma surga". Dari Mālik, ia berkata: Aku mendengar Rasulullah saw. bersabda: "Siapa yang 
menuntut ilmu karena ingin bangga sebagai alim atau menipu orang-orang bodoh atau menarik perhatian orang, Allah swt akan memasukkannya ke dalam neraka". Dari dua hadis itu dapat dipahami bahwa, begitu pentingnya keikhlasan yang harus dimiliki oleh peserta didik. Sehingga pada hadis pertama menyebutkan peserta didik yang tidak ikhlas dalam menuntut ilmu tidak akan mencium aroma surga, dan pada hadis kedua dia akan di masukkan ke dalam api neraka.

4. Menghormati guru. Guru merupakan orang tua kedua setelah yang melahirkan kita, karena dialah yang mendidik kita dengan penuh kesabaran sehingga kita menjadi orang yang berilmu. Maka sebagai peserta didik haruslah menghargai dan menghormati pendidiknya. Keharusan menghormati pendidik tersebut tergambar dalam hadis Rasulullah saw., yaitu: Ubādah ibn Șämit meriwayatkan bahwa Rasulullah saw. bersabda: "Tidaklah termasuk umatku orang yang tidak memuliakan orang-orang dewasa, tidak menyayangi yang kecil dan tidak mengenal hak-hak orang alim (guru)". Peserta didik harus menghormati pendidiknya, sehingga Rasulullah saw. mengatakan bahwa peserta didik yang tidak menghargai dan menghormati pendidiknya bukanlah umatnya.

5. Memiliki potensi. Semua manusia di lahirkan dalam keadaan fitrah yaitu suci, sebagian ulama mengatakan bahwa fitrah tersebut adalah potensi beragama. Sebagaimana hadis Rasulullah saw. yang berbunyi: Abi Hurairah ra. meriwayatkan bahwa Nabi saw. bersabda "Setiap anak dilahirkan menurut fitrah (potensi beragama Islam). Selanjutnya, kedua orang tuanyalah yang membelokkannya menjadi Yahudi, Nasrani, atau Majusi bagaikan binatang melahirkan binatang, apakah kamu melihat kekurangan padanya?"

6. Memiliki kemuliaan (martabat). Sehubungan dengan ini ditemukan hadis antara lain: "Dari Anas, saya mendengarkan Rasulullah saw. bersabda: muliakanlah anak-anakmu dan baguskanlah pendidikannya". Hadis tersebut memang perintah kepada orang tua untuk memuliakan dan mendidik anaknya dengan bagus, akan tetapi dapat juga kita pahami dari hadis tersebut tertuju kepada peserta didik, di mana seorang peserta didik harus memiliki kemulian atau martabat. Adapun di antara membaguskan pendidikan anak pada hadis di atas menurut 
hemat penulis yaitu: memberikan pemahaman-pemahaman kepada anak, memberikan teladan, memilihkan lembaga pendidikan yang baik bagi perkembangan anaknya serta memilihkan teman sebaya yang tidak akan menjerumuskan anaknya kepada jalan yang tidak baik.

7. Memiliki kesamaan derajat. Adapun kesamaan derajat yang di maksud di sini adalah tidak adanya perbedaan antara jenis kelamin, perbedaan suku, warna kulit dan lain-lain dalam menuntut ilmu. Setiap manusia sama hanya saja perbedaannya pada tingkat ketakwaannya. Sebagaimana hadis Rasulullah saw. yaitu Jabir ibn Abdullah meriwayatkan bahwa Rasulullah saw. berkhutbah di depan kami pada pertengahan hari tasyri', beliau bersabda: "Wahai manusia! Ketahuilah sesungguhnya Tuhanmu Esa, nenek moyangmu satu. Ketahuilah bahwa tidak ada kelebihan bagi orang Arab dari orang nonArab, tidak pula ada kelebihan orang nonArab dari orang Arab, tidak ada kelebihan orang yang berkulit merah dari yang berkulit hitam dan tidak pula sebaliknya, kecuali karena takwanya".

8. Memiliki perbedaan kecerdasan. Diriwayatkan dari Abū Mūsā r.a., bahwa Rasulullah saw., pernah berkata: "Sesungguhnya perumpamaan hidayah (petunjuk) dan ilmu Allah swt., yang menjadikan aku sebagai utusan itu seperti hujan yang turun ke Bumi. Di antara bumi itu terdapat sebidang tanah subur yang menyerap air dan sebidang tanah itu rumput hijau tumbuh subur. Ada juga sebidang tanah yang tidak menumbuhkan apa-apa, walaupun tanah itu penuh dengan air. Padahal, Allah swt., menurunkan air itu agar manusia dapat meminumnya, menghilangkan rasa haus, dan menanam. Ada juga sekelompok orang yang mempunyai tanah gersang yang tidak ada air dan tidak tumbuh apa pun di tanah itu. Gambaran tersebut seperti orang yang mempunyai ilmu agama Allah swt., dan mau memanfaatkan sesuatu yang telah menyebabkan aku diutus oleh Allah swt., kemudian orang itu mempelajari dan mengerjakannya. Seperti orang yang sedikitpun tidak tertarik dengan apa yang telah menyebabkan aku diutus oleh Allah swt. Ia tidak mendapat petunjuk dari Allah swt., yang karenanya aku menjadi utusan-Nya". Hadis ini menggambarkan perbedaan antara manusia dalam kemampuan belajar, memahami dan mengingatnya. Menurut Muhammad Usman Najati, ketiga kemampuan ini tergolong dalam pengertian intelektualitas. 
Berdasarkan hadis ini maka dapat dipahami bahwa intelektualitas manusia dapat dikualifikasikan dalam tiga golongan, yaitu: Seperti tanah subur, Yang berarti orang dalam golongan ini mampu belajar, menghafal, da mengajarkan ilmu yang ia miliki kepada orang lain. Seperti tanah gersang, yang berarti orang dalam golongan ini mampu menjaga dan mengajarkannya kepada orang lain, tetapi ilmu yang dia miliki tidak bermanfaat pada dirinya sendiri. Seperti tanah tandus, orang dalam golongan ini tidak tertarik, apalagi menghafal dan mengajarkan kepada orang lain. Dengan demikian sebagai seorang pendidik memang harus bisa memahami perbedaan kecerdasaan peserta didik, sehingga pendidik dapat memilih metode, pendekatan dan media yang tepat sehingga semua peserta didik dapat mencerna materi pelajaran dengan baik. Hal ini dapat dilakukan oleh pendidik dengan mengaplikasikan metode pembelajaran yang bervariasi dan media yang beragam.

9. Memiliki perbedaan emosional. Dari Abi Sa'id al-Khudriy, ia berkata, Rasulullah saw. bersabda: "Ingatlah, di antara anak Nabi Adam AS itu ada yang lambat marah dan cepat terkendali. Ada pula yang cepat marah dan cepat pula terkendali. Ingatlah, di antara anak Nabi Adam AS itu ada yang cepat marah dan lambat terkendali. Ingatlah, sebaik-baik mereka ialah yang lambat marahnya dan cepat terkendalinya. Ingatlah, seburuk-buruk anak Nabi Adam ialah yang cepat marahnya dan lambat terkendalinya." Berdasarkan hadis tersebut, Muḥammad Usmān Najasi mengelompokkan tingkat emosi kemarahan manusia ke dalam tiga tingkatan. Pertama, orang yang emosi kemarahannya lambat, jarang mengekspresikan kemarahannya, kalaupun ia marah ia akan cepat mengendalikan emosinya kemarahannya. Orang semacam ini dikategorikan sebagai manusia yang sangat mulia. Kedua, orang yang emosi kemarahannya terlalu cepat tetapi ia juga cepat mengendalikannya. Ketiga, orang yang emosi kemarahannya terlalu cepat muncul, dia sulit mengendalikannya kecuali dalam waktu yang lama. Orang semacam inilah dikategorikan sebagai manusia yang paling buruk.

\section{E. Penutup}

Peserta didik hendaknya bersungguh-sungguh atau tekun dalam mencari ilmu baik ilmu agama maupun ilmu umum. Apabila peserta didik telah mendapatkan ilmu, maka hendaknya ilmu 
tersebut dipergunakannya dengan baik dan diajarkannya kepada orang lain. Untuk mewujudkan peserta didik yang berkualitas berdasarkan tinjauan hadis dapat dikemukakan sebagai berikut:

1. Rasulullah saw., menjelaskan bahwa ilmu itu hanya diperoleh dengan belajar.

2. Peserta didik diperbolehkan iri hati kepada orang lain yang memiliki ilmu pengetahuan yang luas, sebagai cambuk untuk rakus dalam menuntut ilmu pengetahuan.

3. Peserta didik hendaknya selalu menghafal dan mengulangi pelajarannya, sehingga betul-betul menguasai materi yang telah disampaikan oleh pendidik.

4. Peserta didik yang hadir menuntut ilmu tidak boleh kikir, untuk menyampaikan ilmu kepada orang-orang yang tidak hadir.

5. Peserta didik hendaknya menuliskan, ilmu yang disampaikan oleh pendidik, sehingga terjaga.

6. Peserta didik hendaknya menyadari bahwa dalam menuntut ilmu tersebut, ia berada dalam rida Allah swt., dan mempermudah baginya jalan menuju surga.

7. Peserta didik hendaknya berniat untuk mengajarkan ilmu yang diperolehnya untuk disebarkan dan diajarkan kepada orang lain agar bermanfaat bagi dirinya dan bagi orang lain.

\section{Kepustakaan}

al-'Aini, Abū Muhammad Mā̄mūd bin Ahmad Badr al-Dīn, alSyaikh, al-Imām, al-'Allamah, 'Umdat al-Qāri Syarh Saḥịh alBukhāri, (Beirut: Dār Ihyā' Turas al-'Arabi, t.t.).

al-Bukhārī, Abū 'Abd al-Lāh Muhammad bin Ismā'îl bin Ibrāhīm bin al-Mugirah bin Bardizbah al-Ju'fi, al-Imām, Sahịị alBukhäri, (t.p.: Dār al-Fikr, 1994).

al-Żahabī, Abū 'Abd al-Lāh Muhammad bin Aḥmad, Mizān alI'tidāl fì Naqdir Rijāl (Beirut: Dār al-Ma'rifah, t.t.).

Aḥmad bin Hanbal, 'Abu 'Abd al-Lāh al-Syaibani, Musnad al Imām Ahmad bin Hanbal, (Beirut: Dār Șadir, t.t.).

al-Hakīm, Abū 'Abd al-Lāh Muhammad bin 'Abd al-Lāh al-Naisaburi, al-Hafìz, al-Mustadrāk 'Alā al-Shāhīhain, (Beirut: Maktabul Mathbu'at al-Islamiyyah, t.t.). 
al-Khātib, Muḥammad 'Ajjāj, Ușūl al-Ḣadìs: 'Ulūmuhū wa Muștalāhuhū, (Beirut: Dār al-Fikr, 1989).

al-Nawāwīi, Muhy al-Dīn Abū Zakariyya Yahya bin Syaraf, alMajmū' Syarḥul Muhazzab, (Beirut: Dārul Fikr, t.t.).

-----, Sahịh Muslim bi-Syarh al-Nawāwī, (Beirut: Dār al-Fikr, 1981).

Ash-Shiddieqiy, M. Hasby, Koleksi Hadis-hadis Hukum, (Semarang: Pustaka Rizki Utama, 2011).

al-Zuhaily, Wahbah, Fiqh Imam Syafi'i: Mengupas Masalah Fiqhiyah Berdasarkan al-Quran dan Hadis, terj. Muhammad Afifi dan Abdul Hafiz, (Jakarta: Al-Mahira, 2010).

Ibnu Abu Hatīim, Abu Muhammad 'Abd al-Rahmān bin Abū Hatìm Muhammad bin Idrīs bin al-Munżir al-Razì, al-Imām, al-Ḥafiż, Syaikh al-Islām, al-Jarḥu wa al-Ta'dìl, (Beirut: Dār al-Kutub al-'Ilmiyyah, 1952).

Ibnu Hajar, Abul Faḍil Ahmad bin 'Ali al-'Aśsqalāni, Fatḥ al-Bari, (Beirut: Dār al-Fikr, tt).

-----, Tahżīb al-Tahżīb, (India: Dāirah al-Ma'arif, 1366 H).

-----, Taqrỉb al-Tahdżīb, (t.p: Dār al-Fikr, 1995).

Ibnu Majah, Abū 'Abd al-Lāh Muhammad bin Yazid al-Qazwaini, Sunan Ibn Mājah, (t.p.: Dār al-Fikr, t.t.).

Hasan, A. Qadir, Ilmu Musthalah Hadis, (Bandung: Diponegoro, 1994).

Muslim, Abū al-Ḥusain Muslim bin Ḥajjaj al-Qusyairi alNaisaburi, al-Jamī' al-Ṣaḥih, (Beirut: Dār al-Fikr, 1994). 
